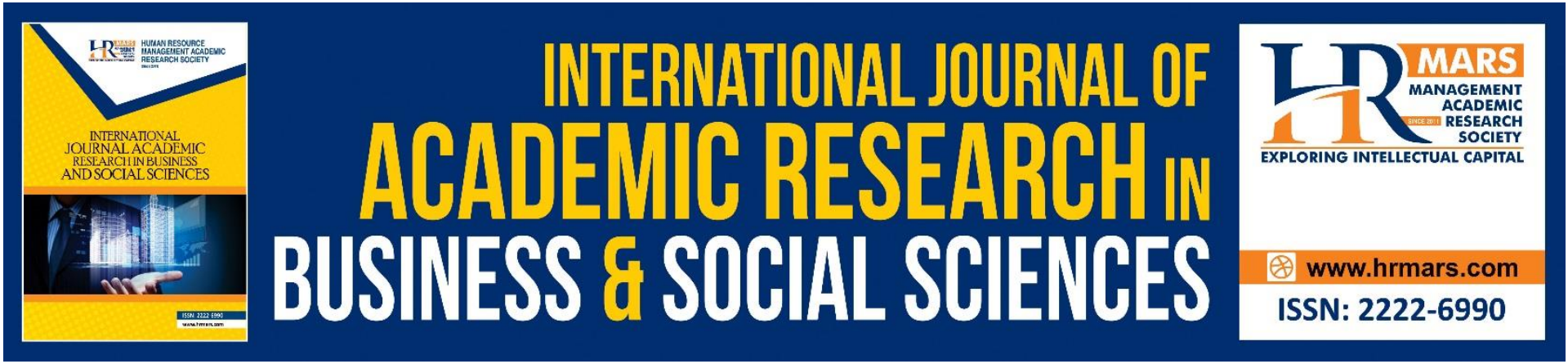

\title{
Legal Literacy of Human Resource Officers in Malaysia
}

Siti Suraya Abd Razak, Izyan Farhana Zulkarnain, Teh Zaharah Yaacob, Siti Zaleha Omain

To Link this Article: http://dx.doi.org/10.6007/IJARBSS/v12-i1/12132

DOI:10.6007/IJARBSS/v12-i1/12132

Received: 16 November 2021, Revised: 17 December 2021, Accepted: 08 January 2022

Published Online: 27 January 2022

In-Text Citation: (Razak et al., 2022)

To Cite this Article: Razak, S. S. A., Zulkarnain, I. F., Yaacob, T. Z., \& Omain, S. Z. (2022). Legal Literacy of Human Resource Officers in Malaysia. International Journal of Academic Research in Business and Social Sciences, 12(1), 2344- 2355.

Copyright: @ 2022 The Author(s)

Published by Human Resource Management Academic Research Society (www.hrmars.com)

This article is published under the Creative Commons Attribution (CC BY 4.0) license. Anyone may reproduce, distribute, translate and create derivative works of this article (for both commercial and non0-commercial purposes), subject to full attribution to the original publication and authors. The full terms of this license may be seen

at: http://creativecommons.org/licences/by/4.0/legalcode

Vol. 12, No. 1, 2022, Pg. 2344- 2355

http://hrmars.com/index.php/pages/detail/IJARBSS

JOURNAL HOMEPAGE

Full Terms \& Conditions of access and use can be found at http://hrmars.com/index.php/pages/detail/publication-ethics 


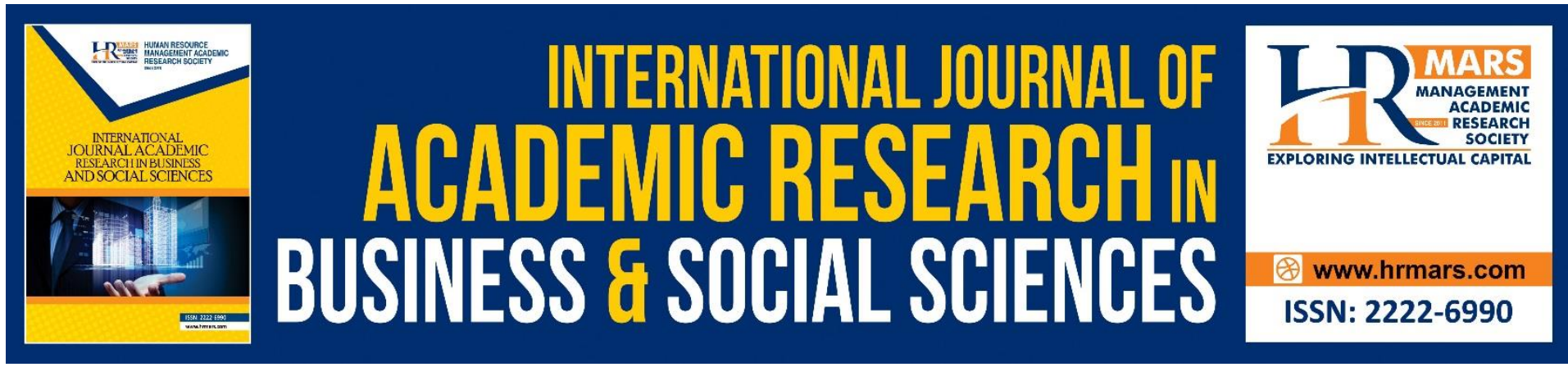

\title{
Legal Literacy of Human Resource Officers in Malaysia
}

\author{
Siti Suraya Abd Razak!, Izyan Farhana Zulkarnain², Teh \\ Zaharah Yaacob ${ }^{3}$, Siti Zaleha Omain ${ }^{4}$ \\ ${ }^{134}$ Universiti Teknologi Malaysia, Johor Bahru, Malaysia, ${ }^{2}$ Universiti Teknologi MARA, \\ Samarahan, Malaysia \\ Corresponding Author Email: sitisuraya@utm.my
}

\begin{abstract}
Legal literacy among human resource officers is essential in the course of dealing with employees in any organisation. Lack of legal awareness among human resource officers has led to the failure in protecting the rights of employees at the workplace and has resulted to legal claims being filed against human resource officers and employers. This paper analyses legal literacy of human resource officers in Malaysia in particular on their awareness of the Employment Act 1955. A total number of 6 human resource officers in Malaysia participated in this study. Qualitative study by way of semi-structured interview is conducted and the data is analysed using thematic analysis. Additionally, content analysis is adopted to analyse secondary sources in form of parliamentary statute and court cases. The findings show that legal literacy of human resource officers influence the protection of worker's rights and benefits at the workplace. It is observed that human resource officers that lacks legal literacy on the Employment Act 1955 tend to disregard worker's right at the workplace. The study concluded that legal literacy is highly recommended to human resource officer since it can enhance professionalism and ensure fair treatment of workers. This research holds a significant implication as it assists the government in improving the education program on human resource. Apart from that, this research contributes to the society as it gives awareness on the importance of hiring a human resource officers with relevant background. Additionally, this study contributes to the theory of legal literacy in analyzing the legal literacy on the employment law.
\end{abstract}

Keywords: Human Resource, Legal Literacy, Employment Law, Industrial Relations, Employment Act 1955

\section{Introduction}

Human resource plays an important role in any organization mainly on the matters relating to recruitment, onboarding, training and payroll of the employees employed in the organization. It is a fact that no product or service could be delivered and produced without the assistance of human being and with that being said, an organization requires skilled people to manage the company and its people. Traditionally, human resource officer is appointed in an organization to bear these responsibilities to manage the workers' affairs 
such as worker's salary and benefits, arrangement of working hours, workplace safety and leave entitlements. Van Vulpen (2021) specified seven human resource basics which include recruitment and selection, performance management, learning and development, succession planning, compensation and benefits, human resource information systems and the human resource data and analytics. Nowadays, the role of human resource is no longer restricted to workers' affairs but it is now extended to the area of talent management and handling industrial and labor relations. For instance, human resource officer involves in the collective bargaining process as representative of employer in the negotiation process with the trade union (Obedgiu, 2017).

Apart from that, human resource officer owes a duty to ensure the company's policy on workers is complied with employment and labour laws. Non-compliance of law can result to fines, penalties and legal suits to the employer or the organization. This can be seen in various cases for instance, Top Glove Sdn Bhd was taken an action for failing to provide an accommodation for foreign workers according to the standard set in the Employees' Minimum Standards of Housing, Accommodations and Amenities (Accommodation and Centralized Accommodation) Regulations 2020 (Kosmo, 2021) and AR Security Services Pte Ltd was convicted by the Ministry of Manpower for failure to pay salaries to workers and failure to provide employment terms and benefits in accordance with the Employment Act (Ministry of Manpower, 2019). According to the Ministry of Human Resource, they have received 5003 complaints of non-compliance of employment law by the employer through the 'Working for Workers' mobile application during the COVID-19 pandemic. It is reported that 1,180 cases are reported for delay in wages payment, 388 cases for deduction of wages not according to procedure, 312 cases for termination without notice, 306 cases of failure to pay overtime and termination benefits and 86 cases for refusing to give annual leave to workers (Yahaya, 2021). Furthermore, according to statistics, there are total of 2,549 complaints made by the employee that has been received by the Labour Department in the year 2021 (Ministry of Human Resource, 2021). One of the factors that contributed to these issues are due to lack of legal literacy on employment law among the human resource officers. Failure of human resource officers in ensuring company policy is aligned with employment law contributes to the unfair treatment of workers at the workplace.

The human resource officer in executing his duties is expected to know the relevant employment law that regulates the affairs and providing minimum rights and benefits of the workers at the workplace. Ignorance of law is not an excuse for the human resource officers and managers. In one decided court case, the Federal Court held that the human resource manager should be made personally liable for the offence as according to the judgment, the human resource manager plays the role on running the human resources activities of an employer. The human resource manager's argument that he did not know that such deductions were contrary to the Fair Work Act was rejected by the court (Grenall, 2016). Therefore, human resource officers are expected to be up to date with the current amendment and introductions of laws regarding employment matters. However, when human resource roles are performed by non-human resource personnel and without legal literacy it has deprived workers of their rights at the workplace.

The objective of this research is to analyse the legal literacy of human resource officers in Malaysia. This study starts off with describing conceptual framework on legal literacy and its importance for the human resource officers. Next, the paper examines the relevant statutes in the Employment Act 1955 that are vital in providing protection and rights to the workers in Malaysia. In the next part of this study it describes the method employed in this 
research to achieve the research objective of this study. In this paper, a qualitative study was conducted to explore the legal literacy of human resource officers in fulfilling their professional duties and responsibilities by looking into their educational background and whether they have attended any training related to the employment laws. Lastly, in the final part of this study it will critically analyse the legal literacy of human resource officers in Malaysia based on the findings.

\section{Literature Review}

According to Jones (2009), legal capability of person refers to a person who has legal literacy, skills and attitudes to deal with issues relating to area of law. Originally, literacy means the ability to read and write. Definition of literacy according to the dictionary includes a knowledge of a particular subject, or a particular type of knowledge. Romig and Burge (2019) stated that literacy has expanded to include the idea of a person being educated and cultured. Community will see how an individual manages his skills and performances in public and as such, under this concept, it is to say that literacy comprises of a person or individual's knowledge as much as how other people perceives such person as knowledgeable based on his skills.

Zariski (2014) pointed out that literacy enables people to influence others because it is a way of communicating or connecting with each other. So, the relationship of literacy to law is a strong one as it assists and encourages people to understand their rights according to the law and how the law governs people. He further elaborated that without literacy people will become intimidated or alienated from law, and this will cause people to have a conflict with the law or they will be unable to obtain help from the law due to the lack of legal knowledge. Our modern societies have developed and with the development in law, it is not sufficient for people to only have a basic literacy in understanding the law, but it goes beyond that. A concept of legal literacy has expanded to include all knowledge and skills required for people to have better interaction with the legal system. A discussion on legal literacy has become one of the popular topics discussed by the scholars in examining the level of understanding of the human resource officers with regards to employment laws. Raza (2021) stated that the absence of legal literacy contributes significantly to deception, exploitation and deprivation. He found that $70 \%$ of the population who lives in rural India with little or no access to their legal rights remain separated from the legal system. Despite the fact that India has undergone a transformation after independence, people still feel the laws are foreign to them. India's apex authority is of the opinion that legal literacy is necessary as a much-needed tool to bring socio-economic equally for people and it can empower any ordinary citizen to seek justice. Article 39A of Indian Constitution provides that the state will arrange a free legal aid for their citizens and this initiative will bring the citizens closer to the law as part of legal literacy initiatives. It is important to take note that the scope of this research was focusing on specific community in India.

Abdul Hamid et. al (2018) mentioned that in relation to the legal literacy of educators in Malaysia, the educators are found to be lacking in the basic knowledge of laws specifically on the education laws and other substantive laws. One of the methods to overcome this issue is by attending any law related courses so that the educators will be able perform their duties and obligations professionally and it would also raise the quality of their education. In addition to that, it is proposed that the laws relating to education to be properly introduced to all levels of education including both public and private, for the betterment of educators. The lack of legal literacy among educators emerged from the fact that most educators are uninformed 
or misinformed about student and teacher rights and have taken no course in school law (Schimmel \& Militello, 2007). On the other hand, Samsudin et. al (2020) highlighted on the importance of legal literacy for Malaysian consumers because literacy deficiencies can lead the consumers to be exposed to legal problems. Legal literacy in consumer's context is whether the consumers have knowledge in consumer laws and therefore, they are able to apply the information they have and spend their income wisely. It is believed that legal literacy could be improved through value, self-efficacy and peer influence, and a comprehensive programme by the government could help in achieving the consumers' legal literacy. Referring to both studies, the authors specifically focused on the legal literacy of educators and consumers in Malaysia.

Khairil et. al (2017) in another study stated that there are two approaches in legal literacy with regards to the enforcement of environmental laws, the first one is continuum approach through the elements of literacy and expertise, whereby under the element of literacy, the enforcement officers should have knowledge on how to read and write legal materials to function effectively and for the expertise, it requires the officers to have knowledge on how and when to call a specialist. Second approach is the legal literacy as a metaphor by influencing the enforcement through thought and judgement elements using one's direction, decision making or good judgement. Referring to the above discussion on the definition and importance of legal literacy, it is also important to see how the legal literacy affects human resource functions. Patrick (2021) in her article discussed the functions of human resource officers including to ensure that the organizations comply with the labor legislation, to maintain a record keeping, to recruit and provide training for the employees, compensation, and to assist the employers in managing the employees' performance problems. She also stated that one of the functions of human resource management functions is basically related to the administration and registration especially with regards to the fundamental legal activities and the execution of legal agreements. It signifies the importance of legal literacy for human resource officers in performing their professional functions. Nevertheless, the question here does the human resource officers in Malaysia have sufficient knowledge or at least the basic knowledge in the employment laws as what people or public expected them to have?

In the context of this research, it is argued that the literacy on the employment law in Malaysia in particular, the Employment Act 1955 (EA 1955) is essential for human resource officer. The EA 1955 provides protection for employees within the scope of the act. Section 2 of the EA 1955 defines employee as any person, irrespective of his occupation, who has entered into a contract of service with an employer under which such person's wages do not exceed RM2,000 a month or any person whose wages exceed RM2,000 a month has entered into a contract of service with an employer in pursuance of which is engaged in manual labour including such labour as an artisan or apprentice, is engaged in the operation or maintenance of any mechanically propelled vehicle operated for the transport of passengers or goods or for reward or for commercial purposes, supervises or oversees other employees engaged in manual labour employed by the same employer in and throughout the performance of their work, is engaged in any capacity in any vessel registered in Malaysia or is engaged as a domestic servant. In the case of Ong Siew Giek @ Cheh Siew Giek v International Footwear (PG) Sdn Bhd [2005] $2 \mathrm{MLJ}$ it was held that the complainant was entitled to the termination benefits as she supervised other employees engaged in manual labour. Furthermore, the EA 1955 is only applicable to employees working in Peninsular Malaysia and the Federal Territory of Labuan (Razninza, 2012). The EA 1955 stipulates the terms and conditions of the contract 
of service, payment of wages, rest days and working hours. Besides that, it also provides the benefit entitlement like medical leave, annual leave, public holidays and overtime rates for the employees. Any term in the contract that is not following the requirement as mention under the EA 1955 will be rendered void. However, employer is free to provide better terms in the employment contract.

Friedman (2007) acknowledged the importance of having comprehensive knowledge in employment laws is essential in order for an organization to expand globally. He further pointed out that difference countries have different laws and regulations relating to the employment law. As such, the human resource officers should be equipped with sufficient knowledge on the employment laws. He provided an example on sexual harassment legislation and precedent in relation to the standardization of legal treatment for sexual harassment and equal treatment of men and women, whereby the United States of America regulated the law on the standardization earlier than the European Community countries. While according to Samuri \& Khan (2021), previous literature on legal literacy has divided the study into two groups. Firstly, is marginalized and discriminated members of society (Macaulay, 2002) and secondly, involving profession that exposed to legal issues, in particular, teachers and medical practitioners (Perry-Hazan, \& Tal-Weibel, 2020; Schimmel \& Militello, 2007). In this study, human resource officers fall under the latter group as they are exposed to legal issues when dealing with employees at the workplace. This study therefore fills the gaps in the area of legal literacy and human resource by analyzing the legal literacy of human resource officers in Malaysia.

\section{Research Design}

This study employed a qualitative research to reach the objectives. The research has carried out interviews, in particular, in-depth semi-structured interview with 6 Malaysian human resource officers as respondents. According to Daymon and Holloway (2002), in-depth semistructured interviews allow same type of data from all respondents to be obtained. Apart from that, interviewing respondents on a similar issue will provide various views and opinions from the participants (Darlington \& Scott, 2002) through personal stories, styles of language used and continuity of experiences (Murray \& Sergeant, 2012). The selection of respondents was based on officers that holds the position of human resource in the organization, specifically in Malaysian private sectors. In qualitative study, the number of respondents in the research in form of interview depends on the objective of the research. Therefore, in the context of this research, 6 respondents are adequate to reach data saturation. Interview method was chosen in this study as it enables researcher to get holistic perspective on an issue and gaining a contextual understanding of the research issues (Brito, 2011). The respondents are required to answer questions related to their legal literacy in the area of employment law and their application of employment law in discharging their duties as human resource officers, apart from that, they have been asked on whether they have attended any trainings on employment law course and on their education background. The interview data was then transcribed and analyzed according to different themes. The respondents in this study are identified as respondent R1, respondent R2, respondent $\mathrm{R} 3$, respondent $\mathrm{R} 4$, respondent $\mathrm{R} 5$ and respondent $\mathrm{R} 6$. The researcher had selected wide range of respondents in terms of academic qualification, participation in employment law training and their working experience so as to reflect their diverse composition and to determine their level of legal literacy. In conducting interviews, ethical element is taken into consideration and the research maintains the confidentiality and profiles of the respondents. Besides that, 
this study adopted content analysis method to analyse the secondary data in form of parliamentary statute, in particular the Employment Act 1955 and the case laws that is related to the discussion.

\section{Analysis and Discussion}

Under this heading, the findings of the qualitative survey of the human resource officers' legal literacy on the employment law are presented and concluded. The following table provides for the presentation on the background information of respondents that involved in this study.

Table 1: Background Information of Respondents

\begin{tabular}{|c|c|c|c|c|}
\hline No. & Respondent & $\begin{array}{l}\text { Academic } \\
\text { Qualifications }\end{array}$ & $\begin{array}{l}\text { Attended } \\
\text { Employment Law } \\
\text { Training Course }\end{array}$ & $\begin{array}{l}\text { Working } \\
\text { Experience }\end{array}$ \\
\hline 1 & $\mathrm{R} 1$ & $\begin{array}{l}\text { Bachelor in } \\
\text { Human } \\
\text { Resource } \\
\text { Management }\end{array}$ & Yes & 9 years \\
\hline 2 & $\mathrm{R} 2$ & $\begin{array}{l}\text { Bachelor in } \\
\text { Management }\end{array}$ & No & 2 years \\
\hline 3 & R3 & $\begin{array}{l}\text { Master in } \\
\text { Corporate } \\
\text { Administration }\end{array}$ & Yes & 29 years \\
\hline 4 & $\mathrm{R} 4$ & $\begin{array}{l}\text { Bachelor in } \\
\text { Human } \\
\text { Resource } \\
\text { Management }\end{array}$ & Yes & 6 years \\
\hline 5 & R5 & $\begin{array}{l}\text { Bachelor in } \\
\text { Management }\end{array}$ & No & 4 years \\
\hline 6 & R6 & STPM & No & 3 years \\
\hline
\end{tabular}

The findings of the interviews indicated that 3 respondents obtained a Bachelor Degree in Human Resource Management while 1 respondent possessed a Master in Corporate Administration. This shows that the respondents are qualified as human resource officer as they were the student of human resource. This is because one of the subjects that students of human resource has to undertake is industrial relations law. Therefore, they are exposed to the knowledge of employment law and the foundation of legal research method. Apart from that, it can be observed that respondents without human resource management background are also hired as human resource officer and this can be seen in the case of respondent R2 and R5. Additionally, one of the respondents in this study is a human resource officer with STPM as the highest academic qualification. This shows that the position of 
human resource office is not necessarily occupied by person with human resource education background. Employer is willing to hire a person without human resource background and even to the extent of hiring a person with only STPM qualification to become their human resource officer.

Respondents were asked on application of the Employment Act 1955 in their organization policies. It is observed that respondents with degree in human resource have a good understanding and application on the Employment Act 1955. This can be seen in the statement made by respondent R1 when being asked about whether their company policy is aligned with the Employment Act 1955:

"Our current company policy is aligned with the Employment Act 1955 for example in terms of working hours, we aware that maximum working hours for workers is 8 hours in a day or 48 hours in a week"

While according to respondent R4:

"The Employment Act 1955 is applied in managing employees of the company such as in the matter of salary, annual leave and termination of contract. For your information, most of the employees in the company earnings are not exceeding RM 2,000."

According to Section 60A (1) of the Employment Act 1955, an employee shall not be required under his contract of service to work more than five consecutive hours without a period of leisure of not less than thirty minutes duration; more than eight hours in one day; in excess of a spread over period of ten hours in one day and more than forty-eight hours in one week. Additionally, the protection and benefits under the Employment Act 1955 covers workers such as mentioned under the First Schedule as any person, irrespective of his occupation, who has entered into a contract of service with an employer under which such person's wages do not exceed two thousand ringgit a month. Hence, from the respondents' statements, it shows that respondent R1 and R4 have the fair knowledge on the Employment Act 1955 and they ensure their company policy are align with the law such as in the matter of working hours, salary, annual leave and termination of contract. Furthermore, respondent R4 states that his company holds a seminar on employment rights annually for the employees. This factor contributes to R4 legal literacy on the employment law. Next, result shows that despite respondent R2 and respondent R5 does not possesses academic background in human resources, they have a moderate understanding on the application of the Employment Act 1955. This is observed in respondent R5 statement:

"Employment Law is important to serve as a protection for employees so they are not mistreated by their employer. For example, during the COVID-19 pandemic, organizational downsizing and employee retrenchment became common. In these cases, employment laws shall become handy to protect employee's rights such as receiving notice before termination and receiving retrenchment benefits."

While according to Respondent R2:

"It is much better to have a written agreement rather than oral agreement. This is because if there is any issue arises, written agreement provides solid evidence to support the case" 
These statements indicated that respondent R2 and respondent R5 are literate in the knowledge of the Employment Act 1955. Respondent R5 states the procedure of termination of contract such as issuance of notice and retrenchment benefits to the affected employees. While respondent $\mathrm{R} 2$ have a good understanding on the principle of employment contract and contract law when she says that oral agreement is acceptable as a form of agreement. Perhaps the exposure of practices in their experience has introduced them to the Employment Act 1955. However, in certain cases respondents without human resource academic background are not well-versed in the application of the related law. For instance, respondent R3 commented that the maximum number of working hours set out in the Employment Act 1955 is not suitable during the pandemic period as his employees are expected to work longer hours with the increasing workload. According to the Employment Act 1955 employee is eligible for overtime payment if been asked to work more than the stated working hours. Additionally, according to respondent R2, as her company is currently facing difficulties in operation during the COVID-19 pandemic period, her company has decided to deduct employee's salary to cope with the situation. She contacted labour office to check on the wage deduction procedure. This shows that respondent R2 is not well-versed on the provision about salary deduction in the Employment Act 1955 and had to rely on confirmation from the labour office to solve the human resource issue.

Apart from that, the respondent 6 remarked that she lacks the basic knowledge in employment law. During interview, she shared her experience in dealing with termination of employee due to misconduct. When asked about the procedure to terminate employee, she says that in one case, she issued a letter of termination to the said employee for absence from work after discussing with the top management. It is observed that respondent R6 is not wellconversant on the procedure to terminate contract as under the Employment Act 1955 and this is demonstrated on the way respondent R6 explains on how she conducted termination of contract of her employee. According to Section 14(1) of the Employment Act 1955, an employer must conduct a proper investigation before dismissing any employee and dismissal can only be done with proper evidence and justification through a domestic inquiry. Additionally, the accused worker must be given the chance to defend himself during the inquiry. If found guilty of the misconduct, an employer may, on the grounds of misconduct dismiss without notice the employee; downgrade the employee; or impose any other lesser punishment as he deems just and fit, and where a punishment of suspension without wages is imposed, it shall not exceed a period of two weeks. In the case of Selvamohan Gopal \& Others v Telekom Malaysia [2013] 1 MELRU 1, the court held that the act of using work-email accounts to forward offensive and racially sensitive e-mails to other employees is considered as a major misconduct and it was found that the employee's dismissal was done with just cause and excuse. However, in this case, respondent R6 immediately terminated the said employee without conducting any domestic inquiry or warning. Hence, indicating that respondent $\mathrm{R} 6$ lack awareness on the procedure to terminate employee and this directly causing unfair treatment toward the said employee. This is different from the way respondent $\mathrm{R} 4$ deals with misconduct cases. This can be seen in respondent R4 experience in dealing with a court suit filed by one of the company's ex-employee due to termination of contract related case. Respondent R4 states that in case of employee's misconduct she shall issue a warning letter to the staff and interview the employee further for investigation. These actions taken by respondent $\mathrm{R} 4$ are following the procedure to terminate workers because of misconduct as stated under the Employment Act 1955. 
Furthermore, the result also demonstrates that 3 respondents in this study did not attend any employment law training while serving as human resource officer. It is essential for a human resource officer to attend an employment law training or courses to improve their legal literacy on Malaysian employment law especially for the human resource personnel without human resource education background. Employment law training offers an insight on the law and procedures in dealing with employee's rights and protection at the workplace besides providing updates on the recent amendment to the employment laws such as the Employment Act 1955 and the Industrial Relations (Amendment) Act 2020. Therefore, it can be observed that the low level of legal literacy demonstrated by respondent R2, R5 and R6 are due to the lack of training on employment law for the human resource officers.

According to Obedgiu (2017), human resource officers in start-up companies are performed by non-human resource personnel compared to larger companies where there is specialized group established for human resource management performed by human resources personnel. This is due to the cost factor in hiring professionals in dealing with human resource matter in their organization. This principle is related to this study as it can be observed that respondent R2, R5 and R6 are human resource officers in a start-up companies while respondent $\mathrm{R} 1$ and $\mathrm{R} 4$ are human resource officers in large companies. Therefore, it can be concluded that employer plays an important role in hiring human resource officers with relevant background to deal with the affairs of their employees. E. M. Berman et. al (2001) mentioned that human resource has significant impact on the careers of other people as they are spending more time on people rather than on anything else. Despite the human resource officers having a human resource management as educational background, it doesn't guarantee that these officers have adequate legal literacy on the employment law. Therefore, it is vital for a human resource officer to stay up to date with the recent changes to employment law by attending conferences and webinars. Apart from that, employer must provide employment law training for their human resource officers and accordingly they can train employees on the compliance with company's policies and procedures. Human resource officer must proactively update the employer's employment contract and employment policies and ensure the terms and conditions are complying with the provisions of the Employment Act 1955 and other related laws. Besides that, it is also equally important for the human resource officers to possess a positive learning attitude in searching for the solution for legal issues confronted rather than waiting for quick fixes such as making calls to labour office or asking for solution from peers. Each and every human resource officer must improve their legal literacy, in particular, knowing how to refer to relevant laws, procedures and case law when solving issues relating to worker's affairs at the workplace. Legal literacy empowers people to make critical judgments about the law and procedures and what are the appropriate actions to be taken in response of any issues related to it (Zariski, 2014). Thus, legal literacy of human resource officers will enable human resource officers to take appropriate actions in dealing with workplace conflict. This situation will allow rights of workers at the workplace is safeguarded.

\section{Theoretical and Practical Implications}

This research holds a significant implication as it assists the government in improving the education program on human resource. Apart from that, this research contributes to the society as it gives awareness on the importance of hiring a human resource officers with the relevant background. Additionally, this study contributes to the theory of legal literacy in analyzing the legal literacy on the employment law. It also highlights the relation between 
legal literacy of employment law and its direct implication on the employee's right at the workplace. It is most crucial for human resource officers to know the relevant law in discharging their roles and responsibilities and this will directly help employers to improve the organisation's governance and professionalism.

\section{Conclusion}

Human resource officers should be aware and understand the employment related laws, in the context of this study, the Employment Act 1955 in managing employees of the organization. They are expected to know the rights of employees and making sure that their employees is treated fairly in the organization. Thus, it can be concluded that respondents without human resource academic background are lacking in basic legal knowledge and application of the Employment Act 1955 and this fact is evidently reflected in the outcomes of the interview. Human resource officer must take the initiative to participate in conference on labour law and employment law training to improve their legal literacy as a human resource officer.

\section{References}

Abdul Hamid, M. I., \& Mohammad, N. A. (2018). Legal literacy of educators in Malaysia: An empirical study. International Journal of Business and Society. 19 (2), 187-204.

Brito, P. (2011). Teen conceptualization of digital technologies, New Media and Society. 14 (3), 513-532.

Daymon, C., \& Holloway, I. (2002). Qualitative research methods in public relations and marketing communications. Routledge. Employment Act 1955 (MY)

Friedman, B. A. (2007) Globalization implications for human resource management roles. Employee Responsibilities and Rights Journal. 157-171. https://doi.org/10.1007/s10672-007-9043-1.

Grenall, T. (2016) Ignorance of the law is no excuse for HR Managers. Retrieved from https://employmentlawmatters.com/employee-relations-ir/ignorance-no-excuse/\#. Ya3NQ9BBw2w.

Ministry of Human Resource. (2021) Statistik Pekerjaan dan Perburuhan. Siri 29 Bil. 3/2021, September. Retrieved from https://www.mohr.gov.my/ebook/istatistik_2021/mobile/index.html

Ministry of Manpower. (2019) Employers Convicted under the Employment Act. Retrieved from https://www.mom.gov.sg/employment-practices/employers-convicted-under employment-act\#/?page $=4 \& q=$

Nadzri, M. N. R. (2012). Malaysian Employment Laws: Tracking the Recent Updates. South East Asian Journal of Contemporary Business, Economics and Law. Vol. 1, 2289-1560.

Nor, M. T. (2021). Top Glove Didakwa Sedia Penginapan Tidak Ikut Standard. Retrieved from https://www.kosmo.com.my/2021/03/16/top-glove-didakwa-sedia-penginapan-tidakikut-standard.

Khairil, M., Jeganathan, C. S., Razman, M. R., Zakaria, S. Z., \& Ismail, M. S. (2017). Influence of legal literacy and communication in the enforcement of environmental laws. International Journal of Business and Society. 20 (10(A), 7199-7208.

Murray, M., \& Sargeant, S. (2012). Narrative psychology. In D. Harper, A. R. Thompson (Eds.), Qualitative research methods in mental health and psychotherapy: A guide for students and practitioners. Wiley-Blackwell. 
Obedgiu, V. (2017). "Human resource management, historical perspectives, evolution and professional development". Journal of Management Development. Vol. 36 No. 8, pp. 986-990. https://doi.org/10.1108/JMD-12-2016-0267.

Patrick, P. (2019). Core functions of human resource management and its effectiveness on organization: A study. International Journal of Research in Economics and Social Sciences. 9 (5), 257-266.

Perry-Hazan, L., \& Tal-Weibel, E. (2020). On legal literacy and mobilization of students' rights from a disempowered professional status: The case of Israeli teachers. Teaching and Teacher Education. 90, 103016. https://doi.org/10.1016/j. tate.2020.103016.

Raza, A. (2021). Legal literacy: A key to socio-economic justice. Young India Fellowship. Ashoka University. 182-191.

Romig, J. M., \& Burge, M. E. (2020). Legal literacy and communication skills: Working with law and lawyers. Carolina Academic Press. Texas A\&M University School of Law Legal Studies Research Paper No. 19-66. Retrieved from https://papers.ssrn.com/sol3/papers.cfm?abstract_id=3491498

Samsudin, N., Abu Bakar, E. M., Jusoh, Z., \& Arif, M. A. M. (2020). Personal and environmental determinants of consumer legal literacy among Malaysian consumers. Malaysian Journal of Consumer and Family Economics. 25 (S1), 27-40.

Samuri, M. A. A., \& Khan, A. S. N. (2021). Legal literacy for Muslim converts in Malaysia. Pertanika Journal of Social Sciences \& Humanities. 29 (3).

Zariski, A. (2014). Legal Literacy: An Introduction to Legal Studies. Athabasca University Press. 1-179. 